\title{
Cada um fazendo a sua parte, dará certo !
}

\author{
Harley E. A. Bicas
}

A operosidade é um impulso vivencial do ser humano, sempre em busca de interações, procurando dominar, ou pelo menos entender, a natureza. A eclosão dessas forças transformadoras é tão imperiosa que não se pode evitá-la ou contê-la, aparecendo como vandalismo, destruição, iconoclasia, rebeldia; ou, quando bem canalizada, como construção, inovação, criatividade, aperfeiçoamento. De uma forma ou de outra essa "vocação" de domínio manifestar-se-á, resultando em uma convivência humana mais agressiva e individualista, ou mais orientada e solidária, na medida em que os membros daquele grupamento forem educados. Entre o bem e o mal, o homem e suas sociedades, o homem e sua formação. Embora, pessoalmente, ele não possua total controle de sua vida (já que também consequência do meio em que sua personalidade é formada), tem discernimento e pode julgar; tem livre-arbítrio e pode decidir como proceder. Será causa, senhor da história.

A comunicabilidade é outra manifestação da vida, tanto maior e mais diferenciada quanto mais complexa a organização da espécie. No homem, a transmissão de conhecimentos e descobertas garante uma acumulação de informações de geração em geração que dá, a cada sucessora, mais condições de controle da natureza e, pelo menos, mais possibilidade de ajustamento entre as pessoas. Mas, claro, de acordo a como são educadas... Portanto, o círculo é vicioso e sua solução favorável depende do bom resultado da educação, o que faz desse termo quase que uma palavra mágica.

Mas o que têm os Arquivos Brasileiros de Oftalmologia a ver com isso? Por quê essa conversa de "forças transformadoras" de cada pessoa e da comunicabilidade entre elas? $\mathrm{Na}$ verdade, temos tudo "a ver com isso". Claro que nossa revista é um veículo de comunicação de achados e propostas, para que sejam transformadoras; um acervo de relatos, arquivos. Educativos, principalmente para brasileiros e, especificamente, concentrando sua atuação na área de Oftalmologia. Mas, por outro lado, antes de oftalmologistas e, ou cientistas so- mos homens e mulheres. E, além disso, brasileiros, com suas qualidades e defeitos, todos muito bem conhecidos.

E então, o que queremos? Obviamente, a qualidade crescente de uma revista, criativa e inspirada, operosa e respeitada pelos seus trabalhos. O que depende de autores e da decisão deles de publicar entre nós, contribuindo para a elevação de nosso nível. Também de nossos revisores, com suas correções responsáveis e educativas. De nossos leitores, com suas vigilâncias e sugestões, seus estímulos e correções. Mas, certamente, só isso não basta. Isso é importantíssimo, sim, e com incontida alegria estamos constatando um movimento de consciência e agregação progressiva em torno dos Arquivos, um de formação de massas críticas, outro de melhor entendimento dos revisores sobre suas funções e de autores também sobre elas. Lentas e ainda quase imperceptíveis, essas transformações estão dando contornos de amadurecimento e essa face dos Arquivos.

Mas, certamente, só isso não basta. O tempo das novas gerações, por vir, clama por nossas atuações formativas de cidadanias; pelo despertar de consciências, provavelmente já bem preparadas, mas ainda adormecidas; pelo encorajamento contra o desânimo. E nem se creia que isso deva vir só dos outros, pois "nada tenho a ver com isso". Ao contrário, é dessa parcela privilegiada da população a que pertencemos que mais se espera e é justamente dela, cujos talentos disponíveis são muitos, que as melhores transformações devem provir.

Nos consultórios e salas cirúrgicas, nas aulas e nas conversas e sem que isso implique em discursos, ou ações orquestradas. Com simples palavras, pequenos gestos e atitudes, refletindo uma inabalável esperança de que, se fizermos a nossa parte, o todo vai dar certo, vai dar certo. Sobretudo e com a responsabilidade de estarmos sob a atenção de alunos, pacientes e colegas ou, também, em nossas outras relações pessoais, não podemos, pelo menos, fazer que dê errado.

E em mutirão, como já se sabe o que há por fazer, ou o que se pode fazer, cada um fazendo a sua parte, dará certo! 